\title{
AN A-SUBJECTIVE COEXISTENCE
}

\author{
GUSTAV STRANDBERG
}

\begin{abstract}
In his article "An A-subjective Coexistence", Gustav Strandberg seeks to elucidate the relation between Jan Patočka's "a-subjective phenomenology" and his understanding of human coexistence. By taking Patočka's critique of Edmund Husserl's phenomenology as a starting point, the author shows how Patočka's displacement of phenomenology from the more traditional phenomenological analysis of the transcendental subject to an analysis of what he calls "the world as a whole" also entails an important proto-political shift in the analysis. The displacement of the position of the subject in favour of an analysis of the world concomitantly implies a shift from the individual subject to an analysis of human coexistence. The phenomenon of coexistence is thereafter analysed in relation to Patočka's understanding of the worldliness of human existence. The article concludes with an analysis of how the question of coexistence is finally addressed by Patočka in his later works and in his attempt to reach an existential understanding of politics. What is thus revealed in Patočka's analyses is a conception of coexistence that is riveted to his understanding of an a-subjective phenomenology and his concomitant analysis of the world.
\end{abstract}

Jan Patočka’s attempt at developing an "a-subjective phenomenology" has been widely discussed and analysed in the reception of his work. For many, it was precisely these analyses that distinguished Patočka as one of the most original philosophers in the phenomenological and post-phenomenological tradition. This article will revisit Patočka's a-subjective phenomenology, but with the aim of analysing a question that has only received scant attention in the reception of his work, namely the question concerning the relation between Patočka's a-subjective phenomenology and his understanding of human coexistence. The article will try to circumscribe how the question of coexistence arises in Patočka's work and how Creative Commons Attribution License (http://creativecommons.org/licenses/by/4.0). 
it is grounded phenomenologically. The contention of the article is that it is only by way of a thorough circumscription of Patočka's a-subjective phenomenology, and of his criticism of Edmund Husserl's phenomenology, that the problem of coexistence can be addressed in his thought.

\section{Displacing Phenomenology}

Patočka's a-subjective phenomenology, and the criticism he directs against Husserl's philosophy, is best summarised by Patočka himself. In the postface to the Czech re-publication of The Natural World and Phenomenology from 1970, Patočka writes that neither can he "identify with the conception of the phenomenological reflection" he once defended nor is it possible to "accept the interpretation of the phenomenological reduction", with which he had identified in the past. ${ }^{1}$ At the centre of both of these concerns voiced by Patočka stands Husserl's conception of "lived experience" (Erlebnis).

The phenomenological reduction revolves around a radicalisation of Cartesian doubt. Faced with the negativity of the phenomenological epoché, Cartesian doubt manifests the fact that the act of doubting as such is indubitable, that the transcendental subject is something that withstands the shattering negativity of the epoché. Patočka concedes that the thesis involved in dubito ergo sum is true. By and through the act of doubting, the act of doubting as such is beyond doubt. What he rejects, however, is the "result" that Husserl famously draws from this doubt. In The Idea of Phenomenology from 1905, Husserl describes this "result" as follows:

Every intellectual process and indeed every mental process whatever, while being enacted, can be made the object of a pure 'seeing' and understanding, and is something absolutely given in this 'seeing.'

According to Husserl, the act of doubting will not only guarantee that the subject performing the act in question is ascertained, but that the lived experiences of this subject are guaranteed as well. Patočka, on the other hand, rejects this "result". First of all, he questions the veracity involved in the introspective reflection that is at stake in Husserl's phenomenology. Even if Patočka does not call into question

1 Patočka Jan, "Přrirozený svět v meditaci svého autora po třiatřiceti letech", in Patočka J., Fenomenologické spisy II, Praha, OIKOYMENH, Sebrané spisy Jana Patočky 7, 2009, p. 277. All translations by the author unless indicated otherwise.

2 Husserl Edmund, The Idea of Phenomenology, Dordrecht, Kluwer Academic Publishers, 1990, p. 24. 
the fact that the act of doubting is guaranteed, he criticises the idea that this reflection will give rise to knowledge that transcends this certainty. In relation to the earlier quote from Husserl, Patočka therefore writes:

One has to ask oneself what 'absolutely given' means here, if it only means 'absolutely certain', or if it means 'originally given. The first possibility is guaranteed, but that does not entail a knowledge that transcends this fact. The other possibility is certainly false since I reflectively comprehend thought as an object even though it originally is an act. ${ }^{3}$

The problem with such an introspective reflection is that, as Patočka continues, what you comprehend through it is "the perceived and the recollected and so forth". ${ }^{4}$ According to Patočka, one will, in other words, never grasp the act of thinking - i.e., its procedural character - but only thought as an object for thought. In this critique of Husserl one can already anticipate Patočka's understanding of human existence as movement. When one is attempting to grasp human existence with the help of an introspective act, one is, Patočka contends, engaged in an attempt to objectify human existence, to reduce existence to an object for reflective consciousness. That which escapes such an attempt, however, is the very movement of human existence. Human existence is a dynamic process of actualisation that will never reach the kind of rest or stability necessary for introspective reflection. The distinction, introduced by Husserl, between "bodily givenness" and "improper givenness" is therefore no longer relevant, since, as Renaud Barbaras has expressed it, "the division between presence and absence is so to speak blurred (brouillé)". ${ }^{5}$ It is blurred by virtue of the fact that human existence is not present to itself. Since human existence is an existence in constant movement, its presence to itself is at the same time marked by a constitutive absence.

The capital implication to be drawn out of Patočka's critique of Husserl is that the experiential transparency of the subject cannot serve as a foundation for phenomenology since it not "originarily given", but is instead permeated by a constitutive absence. One cannot grasp the structure of human existence with the help of introspective self-reflection, since such a perception of cogitationes "with the help of an 'inner gaze", as Patočka puts it, "is a myth".6 This particular myth, however,

3 Patočka Jan, Vom Erscheinen als solchem. Texte aus dem Nachlass, Munich, Verlag Karl Alber, Orbis Phaenomenologicus 2: Quellen 3, 2000, p. 117.

4 Ibid., p. 118. My italics.

5 Barbaras Renaud, Louverture du monde - Lecture de Jan Patočka, Chatou, Les Éditions de la Transparence, 2011, p. 55.

6 Patočka Jan, "Epochē and Reduction: Some Observations", in Učník Lubica, Chvatík Ivan, Williams Anita (eds.), Asubjective Phenomenology: Jan Patočka's Project in the Broader Context of his Work, 
rests upon Husserl's claim that the subject does not appear; that the subject, in contradistinction to appearances, is present by way of an original transparency and givenness. The Cartesian doubt that Husserl relies upon does not, Patočka contends, reveal any "content" or lived experience. The only thing that it makes manifest is the fact that all appearances appear to somebody and that this "somebody", as a mere receiver for the given, is indubitable:

The ego in ego cogito is, it is true, immediately certain, but this certainty is not a certainty that relates to content. It is, on the contrary, only a simple certainty of being without any content, with the exception of one thing: the ego is that in relation to which appearances appear, appearing as such, the phenomenal field, is its appearing. ${ }^{7}$

According to Patočka, phenomenology should not preoccupy itself with the lived experience of the subject, because this "content" is not guaranteed through any kind of methodological doubt. The distinction between appearances and lived experience is, for this very reason, questionable according to Patočka - and something that violates the principle of phenomenology. It leads, as he puts it, to an unsatisfactory ontology in which there are two kinds of being. ${ }^{8}$ On the one side stands consciousness, which is immediate and which lets everything else appear, and, on the other side, the real, which cannot appear by and of itself, but can do so only through the mediation of subjectivity.

The phenomenological reflection, together with the phenomenological reduction, must, in other words, be set aside, according to Patočka. But at the same time, the epoché must itself be preserved. The epoché is, as Patočka famously claims, possible even without the phenomenological reduction. ${ }^{9}$ What the epoché makes manifest is, however, not the immediacy of the subject, but appearing as such: the very structure of appearing, and the structure out of which every singular appearance receives its meaning. This is also the point at which Patočka introduces his idea of a "phenomenological difference" between appearances and appearing as such, together with his claim that it is precisely this difference that Husserl overlooked in his analyses. ${ }^{10}$ This structure of meaning is something that Patočka, in his later writings, will analyse not only in terms of appearing as such, but also

Nordhausen, Verlag Traugott Bautz GmbH, Libri Nigri 41, 2015, p. 49.

7 Patočka Jan, "Der Subjektivismus der Husserlschen und die Forderung einer asubjektiven Phänomenologie", in Patočka J., Die Bewegung der menschlichen Existenz, Stuttgart, Klett-Cotta, Ausgewählte Schriften IV: Phänomenologische Schriften II, 1991, p. 302.

8 Patočka Jan, "Epochē and Reduction: Some Observations", op. cit., p. 47.

9 Ibid., p. 51.

10 See: Patočka Jan, Vom Erscheinen als solchem, op. cit., p. 63. 
as "the world as a whole" (svert vcelku). Appearing as such is, as he himself puts it in one of his many notes, "the a priori world phenomenon". ${ }^{11}$ By and through the epoché, the world is made manifest, according to Patočka, and not the immediately experienced transparency of the subject. Patočka describes this as follows:

What belongs to the I [das Ichliche] is arguably never perceived in itself and by itself, nor is it ever immediately experienced. Rather, I is only experienced as the organizational centre of a universal structure of appearance that cannot be reduced to a being as such, appearing in its particularity [Einzelsein]. We call this structure 'world' and are justified in calling it this, since it is that which is encountered in the epoche and thereby neither denied nor contested, but brought to light only out of its original anonymity. The self is only what it is in its being exposed [Auseinandersetzung] to the world. ${ }^{12}$

It is this structure that phenomenology, according to Patočka, should study: a structure that is not, as he notes, "a being as such", nor an appearance among others. The world is not an appearance, it does not itself appear but withdraws in each presence, doing so in such a way that singular appearances can manifest themselves. In this sense, the world "is" not; rather it only manifests itself in human experience as the constitutive absence or, as Patočka describes it in the quote above, "anonymity" of each and every presence. The world is thus something that manifests itself in "an ambiguous way". It shows itself "as that which do not itself-show-itself", as "the announcement (das Meldende) that, by showing itself, manifests the not-showing-itself as such". ${ }^{13}$ The world is thus not to be equated solely with our surrounding world (Umwelt), it is not something that can be reduced to the inner-worldly presence of appearances, but is something more original than presence itself - the absent condition of possibility for all appearances and all presence. Patockka's insistence upon the fact that the world, appearing as such, does not appear - that it cannot be equated with appearances - does not, however, imply that it is something that transcends human experience completely. Patočka is not, and this is important to emphasise, defending a metaphysical position here. He remains faithful to the impetus of phenomenology.

But how, then, do we experience this absence, if it is not given as an appearance? First of all we experience it in and through each appearance. Each appearance gives testament to appearing as such. But when we encounter particular appearances, the world disappears. In fact, it is only by virtue of this disappearance that

11 Ibid., p. 125.

12 Patočka Jan, "Epochē and Reduction: Some Observations", op. cit., p. 49.

13 Patočka Jan, Vom Erscheinen als solchem, op. cit., p. 160. 
particular appearances can appear: it is only by and through the disappearance of the world that particular appearances can appear as delimited. There are, however, also experiences in human existence when we encounter this disappearance or negativity as such; experiences when the world is given as negativity and not only as the absent condition of possibility for particular appearances. Following Jaspers and Heidegger, Patočka calls these experiences "limit experiences" (Grenzsituationen). ${ }^{14}$ These experiences - which according to Patočka can be found in attunements such as anxiety and boredom, but also in the frontline experiences of the First World War and in the experience of sacrifice - are experiences of "that" which remains when all appearances have become meaningless. By and through these experiences, man is, as Heidegger notes apropos anxiety in Being and Time, confronted with a "nothing and nowhere", which make inner-wordly beings or appearances so utterly meaningless that "the world is all that obtrudes itself into worldliness". ${ }^{15}$ It is, in short, only - as Patockka describes it in the Heretical Essays by "passing through the experience of the loss of meaning" that the meaningfulness of the world as a whole is experienced. ${ }^{16}$

Here one can also call attention to the fact that there are some striking similarities between this conception of the world, which we find in Patočka's writings, and Eugen Fink's cosmological understanding of the concept; an influence that Patočka himself clearly attests to. ${ }^{17}$ What Patočka and Fink both try to come to terms with in their respective attempts at analysing the world phenomenologically is the tension that permeates our understanding of the world.

This tension is something that revolves around what Fink calls "the vacillation of the world". The world vacillates, Fink writes, between being, on the one hand, a "human world", i.e. the world in which we live our lives, the surrounding world

14 Patočka's discussions with Jaspers can be found in the article "Co je existence?", which Patočka dedicated to Jaspers after his death. Although Patočka is critical of some aspects of Jaspers' thought, he commends him for having introduced an analysis of precisely those "limit experiences" of human existence. See: Patočka Jan, “Co je existence?”, in Patočka J., Fenomenologické spisy II, Praha, OIKOYMENH, Sebrané spisy Jana Patočky 7, 2009, p. 345.

15 Heidegger Martin, Being and Time, New York, State University of New York Press, 1996, p. 175.

16 Patočka Jan, Heretical Essays in the Philosophy of History, Chicago, Open Court, 1996, p. 60.

17 There are a number of passages in Patočka's work in which he alludes to Fink's cosmology, both implicitly and explicitly. But Fink's influence on Patočka's thought is perhaps brought forward most clearly in a letter that Patočka wrote to Fink in December 1971. Here, Patočka writes the following laudatory remarks to Fink: "I have of late reread almost all of your books anew, and even though there are many things that I cannot completely reconcile myself with, I must tell you Eugen, that I have seldom been so inspired as I was when rereading and rethinking your work. Your cosmological approach is the most radical and enlightening one imaginable, clearer and perhaps more fruitful than the ontology of Heidegger". See: Fink Eugen, Patočka Jan, Briefe und Dokumente 1933-1977, Freiburg/Munich, Karl Alber/OIKOYMENH, Orbis Phaenomenologicus 2: Quellen 1, 1999, pp. 106-107. 
that encloses all of our actions and all of our understanding, and, on the other hand, a "cosmic world", that is, a world which in and of itself is nothing but absence and withdrawal and that we are only confronted with in specific limit experiences. ${ }^{18}$ This vacillation is also something that we find in Patočka's work, and then perhaps most clearly in the Heretical Essays, in which it is understood by way of the relation between light and darkness, between presence and absence. But it is also, as I will try to explicate further on, something that is central to the conception of coexistence, which Patočka develops in his later work.

However, the epoché is not only something that manifests the absence of the world, according to Patočka. It is not only something that manifests the primordiality of the world as a whole, but something that also manifests the fact that human existence cannot be studied or analysed beyond or before this very structure. It manifests the fact that human existence is not an immanence removed from the world, but that it is itself worldly; that human existence, as Patočka himself writes in the earlier quote, only is what it is by "being exposed to the world". Patočka's a-subjective phenomenology is therefore neither a negation of the subject nor a negation of human existence as such. The alpha privativum which he assigns as a prefix to the subject is rather, as Heidegger notes concerning his own use of the term in relation to the Greek understanding of truth (aletheia), something that "expresses the fact that something is lacking in the word it prefixes". ${ }^{19}$ That which human existence is lacking is not, however, something that it could one day find or appropriate to make itself "whole". Human existence is not lacking "something", but must rather be conceived of as a lack in and of itself. It is this lack and restlessness that constitutes the movement of human existence. By virtue of this movement and transcendence, the proper nature of existence is, in fact, that which is "foreign" to it. One can only, as Patočka formulates it, "catch sight of the ego, or rather make it visible, through that which it concerns itself with, through that which it projects and does in the phenomenal sphere". ${ }^{20}$ The I is thus, as he also puts it, "never given, but only given-with". ${ }^{21}$ The meaning of human existence is, in other words, only something that we can approach by way of the relations that we, as humans, create with other appearances in the world. It is, phrased somewhat differently, by way of

18 Fink, Eugen, Existenz und Coexistenz - Grundprobleme der menschlichen Gemeinschaft, Würzburg, Königshausen \& Neumann, 1987, p. 81.

19 Heidegger Martin, The Fundamental Concepts of Metaphysics: World, Finitude, Solitude, Bloomington, Indiana University Press, 1995, p. 29.

20 Patočka Jan, "Der Subjektivismus der Husserlchen und die Möglichkeit einer 'asubjektiven' Phänomenologie", in Patočka J., Die Bewegung der menschlichen Existenz, op. cit., p. 283.

21 Patočka, Jan, Vom Erscheinen als solchem, op. cit., p. 99. 
our relationality to other people, to things in our surroundings, and, finally, to the world as a whole that our singular meaning is constituted.

Phenomenology is therefore displaced according to Patočka. It no longer takes the subject as its starting point and ground, but the subject's position in the analysis is displaced and transposed in favour of an analysis of the world as a whole, and of human existence in relation to the world.

\section{A Worldly Coexistence}

The restless negativity of our being constantly forces us outside of ourselves. We are, in short, constantly exposed to an "outside" that is more proper than any purported "inside". However, this exposure to the world simultaneously implies an exposure to others. The world is never "my" world, but is instead a world that I share with other people. Patockka describes this as follows, by focusing on the temporal and spatial dimensions of the worldliness of human existence:

My determination by the world, for example in relation to time means that: I am temporally before myself and retain the already, however the not yet and no longer is not only $m y$ already and so forth, but common. Similarly, my being-contained, my therein, is not only my therein. ${ }^{22}$

In this somewhat elliptical passage, Patočka is trying to describe the sharing of existence by and through the world. By being exposed to the world, human existence is also always already exposed to a world that is common and shared in all of its forms and manifestations. The displacement at stake in Patočka's a-subjective phenomenology is therefore not only a displacement of the subject for the sake of the world, but also a displacement of the subject, or the individual, for the sake of coexistence. On a formal, and thereby ontological level, this coexistence is something that characterises all appearances, including man. All appearances are, according to Patočka, co-appearances. Each thing is, as he writes, "a being for others", as delimited and individuated they are "always outside of themselves in another milieu". ${ }^{23}$

This is therefore the point at which Patočka's a-subjective phenomenology becomes intertwined with his understanding of human coexistence. But this is

22 Ibid., p. 106.

23 Patočka Jan, "Přirozený svět v meditaci svého autora po třiatřiceti letech", op. cit., p. 312. 
also the point at which one can begin to discern the contours of the critique that Patočka directs against Husserl's phenomenology. ${ }^{24}$ Because in relation to Husserl's analysis of intersubjectivity, at least in the static form that Husserl develops in the Cartesian Meditations, it is clear that Patocka's conception of coexistence is radically different. The very question Husserl raises in the fifth Cartesian meditation, namely the question of how the subject constitutes the meaning of the other, is completely overturned in Patočka's thought. There is simply no individual subject that, in a second step, reaches out towards an other that is foreign to it. On the contrary, human existence is, by virtue of its worldliness, always already shared. The negativity of its movement simply implies that the "co" of coexistence is only a pleonasm of existence itself.

In this respect, as in so many other areas of Patočka's thought, there are clear similarities between his understanding of coexistence and Heidegger's analyses of "being-with" in Being and Time. Being-with or coexistence is, as it is for Heidegger, an existential structure of human existence and thus congenial to the human condition as such. But this notwithstanding, there are some crucial differences between Patočka's conception of coexistence and Heidegger's understanding of "being-with" - differences that concern precisely the worldliness of being-in-common. This is something that Patočka most clearly expresses in the lecture series Body, Community, Language, World. Contrary to Heidegger, who claims that $D a$ sein constantly runs the risk of losing itself in the world, of getting entangled in the world of pragmata with which it is occupied, Patočka explicitly states that his conception "is fundamentally different". ${ }^{25}$ Even though Patočka is well aware of the tendency of human existence to escape itself and take refuge in the world of things, he will nevertheless stress that the relation of human existence to the world is not only negative, but also positive. It is not, first and foremost, a self-loss, he writes, "but the condition of possibility of self-discovery". ${ }^{26}$ The relation of human existence to the world is a condition of possibility for self-discovery, according to Patočka, because there is no self before or beyond the world. This also means that we cannot even relate to ourselves without at the same time relating to the world and to others. Our self-relation must, as he puts it, in order for this relation to be actualised, "go round about through another being", since we "relate to ourselves by relating to the other, to more and more things and ultimately to the universe

24 This critique is something that Patočka never fully developed, but that he alludes to in a number of passages in his work. See, for example: Patočka Jan, "Der Subjektivismus der Husserlchen und die Möglichkeit einer 'asubjektiven' Phänomenologie”, op. cit., p. 280.

25

26

Patočka Jan, Body, Community, Language, World, Chicago, Open Court, 1998, p. 49.

Ibid., p. 49. 
as such". ${ }^{27}$ Patockka's earlier claim that one can only "catch sight of the ego (...) through that which it concerns itself with, through that which it projects and does in the phenomenal sphere", must in this respect be qualified further. Here we have to add that we can we can only "catch sight of the ego" by and through the relations we have with other people: we cannot relate to ourselves without a sharing of ourselves. Heidegger's inability to recognise this common nature of the world derives, as Patočka expresses it, "from his bias against everything common, everything public; that is understood as a fall". ${ }^{28}$ But according to Patočka, Heidegger's partisan stance is something that stands in stark opposition to the principle of phenomenology. It is, as he puts it, "something that is not derived from the matters themselves". 29

What Patočka is drawing attention to in his critique of Husserl and Heidegger is, in other words, that human existence, by virtue of its worldliness, is always already exposed to a world that is common and shared - that human existence simply cannot tear itself loose from its relation to the world and to others. There is, quite simply, no such thing as an authentic existence without others, as Heidegger seems to propose, and there is no such thing as a subjective immanence removed from the world and from others, as Husserl suggests. Patočka is, in other words, critical of both Husserl's and Heidegger's understanding of coexistence since both of them are ignorant of the shared and common worldliness of human existence.

In relation to this worldliness it is, however, also important to return to the earlier discussion concerning "the vacillation" of the world. Because the common worldliness that Husserl and Heidegger, albeit in different ways, failed to account for is not only our surrounding world, the objects in the world that we engage with together with other people, but also what Fink calls the "cosmic world": the absence that permeates the world as a whole. In this sense, it is not only the world that vacillates, but also our worldliness and, as a consequence, our coexistence with others. We do not, in short, only share objects or beings with each other, but we also share the nothingness that characterises our worldly existence.

In order to elucidate this tension inherent to human existence, I would now like to turn to Patočka's understanding of the three movements of human existence, since it is precisely in Patočka's analyses of the inherent coexistence, the co-movement, of each of these movements that this tension is brought out most clearly.

27 Ibid., p. 31.

28 Ibid., p. 68.

29 Ibid., p. 68. 


\section{Co-Movement}

When Patočka, in the essay "Die Selbstbesinnung Europas" from the beginning of the 1970s, revisits and, once again, criticises Husserl's conception of the world, he does so by drawing attention to the question of temporality. The world can never, he claims, be grasped through intuition. It is not an object that in any way or form can be represented by an epistemic subject. The world is, on the contrary, he writes, "a field of possibilities, however, not as represented possibilities, but possibilities for the actual experience" of human existence. ${ }^{30}$ The world is, in this respect, nothing that stands opposed to the epistemic subject as an object of its theoretical gaze, but something that human existence lives by and through something it moves with temporally. The potential nature of the world, the fact that it manifests itself as a field of possibilities for action, entails that it, in short, must be understood from out of the temporality of human existence. The world has, Patočka writes, originally a "futural character". 31 The world is "futural" in nature, according to Patočka, precisely because it is given as a field of possibility for human existence. It is by virtue of the potential nature of the world that it is tied to the futural temporality of man. The act of temporalisation is, as Dragoş Duicu has shown, something that always takes place "from the future in the sense that it is identified with the possible, with that which can be actualized" ${ }^{32}$ However, this also implies that all of the three movements are futural in nature, although they inflect this futural temporality in different ways: according to Patočka, we can relate to our future in a past, present and futural tense. ${ }^{33}$

The worldliness of human existence is, in other words, temporal, which means that the world manifests itself differently depending on which temporal ecstasy our experience is structured by. But since Patočka understands the question of coexistence as something that is itself grounded in the worldliness of human existence, the structure of our coexistence will also manifest itself by and through a temporal difference. When the emphasis is placed on the past, as in the first movement of human existence, the world is given as something that is already there. It is a pre-given whole with which human existence, from its inception at birth, is intertwined. Patočka therefore also understands this movement in terms of what he

\footnotetext{
Patočka Jan, "Die Selbstbesinnung Europas”, in Perspektiven der Philosophie, 20, 1990, p. 254.

Ibid., p. 254.

32 Duicu Dragoş, Phénoménologie du mouvement - Patočka et l'héritage de la physique aristotélicienne, Paris, Hermann, 2014, p. 161.

33 This is brought forward most clearly by Patočka in the Czech postface to his habilitation work. See: Patočka Jan, "Přirozený svět v meditaci svého autora po třiatřiceti letech", op. cit., p. 318f.
} 
calls a "cosmic" consonance with the world: it is by virtue of this first movement that human existence becomes a cosmic or worldly existence. ${ }^{34}$ The first movement of existence is, in other words, the movement by and through which human existence is emotionally moved by the cosmic absence of the world. The worldliness of the first movement of human existence should thus not be understood as a movement in which we interact with inner-worldly things in our surroundings, but rather as a worldliness in which we are submerged in, and enclosed by the absence and negativity of the world as a whole. The first movement of human existence is something that exposes us to the always already of our intertwinement with the world. This temporal structure of an always already also manifests itself through the coexistence which characterises the first movement. It is a form of coexistence that we, from birth, are accepted and enclosed by. This coexistence is not, however, a coexistence in which we share objects with one another. It is not a coexistence centred around tangible things or products, as Hannah Arendt, for example, suggests in her analyses, but a coexistence in which we share the no-thingness of the world. ${ }^{35}$

Yet, this nothingness does not manifest itself explicitly in the first movement, it is not something that we relate to and share consciously. In the first movement we are, on the contrary, shielded and protected from this ever-pressing shadow of the world by our caretakers. Concealment has here, as Patočka notes, "the peculiar form of screening, shelter, safety": by being cared for and protected by those close to us, we are shielded from our exposure to the inherent negativity of the world. ${ }^{36}$

In the second movement, the temporal emphasis is placed on the present, on that which is actual and ready at hand. Here we relate to that which is present and transform the passivity of the past into "given possibilities for a transformation of presence." ${ }^{37}$ This is also a movement in which we constantly run the risk of losing ourselves, of becoming alienated in the objects we use in order to prolong our life by and through labour. However, we lose ourselves in this movement by losing the world, or by losing the worldliness of our existence: ensnared and occupied by the pragmata of our surroundings, our horizons dwindle and disappear. The second movement of human existence is, in this sense, a movement of worldlessness - in

34 Patočka Jan, "Leçons sur la corporéité", in Patočka J., Papiers phénoménologiques, Grenoble, Jérôme Millon, 1995, p. 104.

35 Here I am alluding to Arendt's analysis of human coexistence in The Human Condition and, more specifically, to her descriptions of the phenomenon of "work" as a pre-condition for the constitution of a common world. See: Arendt Hannah, The Human Condition, Chicago, University of Chicago Press, pp. 136-174.

36 Patočka Jan, "Přirozený svět v meditaci svého autora po třiatřiceti letech", op. cit., p. 320.

37 Ibid., p. 318. 
the meaning that Arendt gave to the word. But since the coexistence of man is congenial to the worldliness of his or her existence, the worldlessness of the second movement also implies that our coexistence with others tends to disappear in this movement. The world is that which is in common, and when the world as such disappears, or is overshadowed by the interests of the present, so does our coexistence with others. By and through the worldlessness of the second movement, our coexistence with others will, in this respect, to an ever-larger degree take the form of an atomism, such that other people are seen as rivals and competitors. The being-with of the second movement is thus also a being-against one another. This does not, however, imply that we completely lose our coexistence with others when engaged in the demanding and pressing tasks of the present. On the contrary, even this isolation is, Patočka underlines, a "movement shared". ${ }^{8}$ But this form of coexistence is, nevertheless, a curious form of sharing, since we share the not-sharing of the world: we share the fact that we are all engaged in an activity where our own self and its prolongation in labour is the sole purpose of our lives. It is, in short, a coexistence in which we all paradoxically take part in a common privatisation of the world.

The third movement of human existence is the movement in which human existence is faced and confronted with the world as a whole. It is the movement of a true worldliness, since it is the movement in which the futural aspect of the world is brought forward explicitly. In relation to the second movement of existence, the third is thereby something that manifests the worldliness of human existence. This is also why Patockka can claim that the third movement of existence shatters that which separates us from each other. ${ }^{39}$ It shatters the atomistic narcissism of the self-enclosed I that characterises the second movement. In a certain respect, the coexistence of the third movement thus bears some striking resemblances to the first movement by virtue of its worldliness. But unlike the first movement, the third is an explicit confrontation with the world as a whole. Whereas the world manifests itself through affects and emotions in the first movement, the third movement confronts man with the world in its proper negativity. For Patočka, this means that the world is no longer something that expresses itself through closure and warmth, through the harmonious always already of the first movement, rather, it is something that disorients us. By and through the limit experiences of the third movement - experiences in which we always relate to our future, and finitude, in an explicit way (be it through anxiety, boredom, sacrifice or front experiences) - all

38 Patočka Jan, Body, Community, Language, World, op. cit., p. 150.

39 See for example: Patočka Jan, "K prehistorii vědy o pohybu: svět, země, nebe a pohyb lidského života”, in Patočka J., Fenomenologické spisy II, op. cit., p. 200. 
that which sheltered us from the negativity of the world trembles, shivers and disappears. In the Heretical Essays, Patočka will himself characterise this as follows by describing the loss of this shelter as an experience when "scales" fall from our eyes:

In the moment when life renews itself everything is cast in a new light. Scales fall from the eyes of those set free, not that they might see something new but that they might see in a new way. It is like a landscape illuminated by lightning, amid which humans stand alone, with no support, relying solely on that which presents itself - and that which presents itself is everything without exception. ${ }^{40}$

The limit experiences of human existence shatter everything accepted life rested upon. This also means that they shatter the harmonious coexistence that manifested itself in the first movement. The coexistence of the third movement is, in this respect, a shaken coexistence, or, as Patočka famously described it, a "solidarity of the shaken". To begin with, this solidarity or coexistence is worldly too, but not in the same respect as the first movement. Not only is it not a coexistence with others in the homogeneous and harmonious form we find in the first movement, but it is also not an atomistic and heterogeneous form of coexistence, as it appears in the second. The solidarity of the shaken is, on the contrary, as Patocka puts it in the Heretical Essays, a "unity in conflict". ${ }^{41}$ It is a unity in conflict since the third movement of existence implies an existence in relation to the world as a whole and this world is something that brings us together at the same time as it individuates us. It is a world in common, but it is also a world that forms the background against which we are singularised and individuated - a world that joins us together at the same time as it separates us from each other.

Homogeneity and heterogeneity are therefore problematic concepts in this context. What Patočka is trying to grasp with the concept of the solidarity of the shaken is rather a form of coexistence that takes place by and through a tension between the closeness of homogeneity and the distance of heterogeneity. This tension is entirely constitutive of the form of coexistence that comes to the fore in the third movement. However, since the third movement, by virtue of being the movement of freedom, is the political movement par excellence according to Patočka, the tension found within the coexistence of this movement is also constitutive for political life as such. If this tension were to give way to a homogeneous unity, all political differences would disappear and politics would be totalised; by the same token, if it gave way in favour of a heterogeneous dissolution, the common nature

40 Patočka Jan, Heretical Essays in the Philosophy of History, Chicago, Open Court, 1996, p. 40.

41 Ibid., p. 41. 
of politics would itself be lost. In other words: in order for politics to be possible, there must exist precisely a "unity in conflict", that is, a unity that is constituted by the conflicts permeating political life.

But how are we then to understand this political form of coexistence, or solidarity, that is brought to light in the third movement of human existence? First of all, it is important to note that the kind of coexistence that Patockka describes here can be equated neither with an "associational" nor a "dissociational" form of politics. ${ }^{42}$ What is striking in Patočka's thought is, on the contrary, his understanding of politics as precisely a "unity in conflict". The conflicts of politics, its antagonistic or agonistic dimension, are in this respect constitutive of politics, but they are also, paradoxically enough, constitutive of the form of coexistence, unity or solidarity that political life rests upon. By and through the conflicts of political life, people continuously affirm that they belong to the same community; by and through political conflicts a shared sense of the common is constituted. And even though Patoč$\mathrm{ka}$ at times describes this with the help of other concepts, it is clear that this is what is at stake when he writes that "polemos binds together the contending parties, not only because it stands over them but because in it they are one". 43 In politics we are "one", but conflicted at the same time; we belong to the same political community, but a community that is pierced through by conflict - we coexist together and against one another at the same time. ${ }^{44}$

\section{Conclusion}

We can then conclude by stating that the question of coexistence is something that (throughout Patočka's later texts) is riveted to his understanding of an a-sub-

42 For a description of this difference, in which Arendt is understood as the leading representative of the "associational" conception and Carl Schmitt as the representative of the "dissociational" one, see: Marchart Oliver, Post-Foundational Political Thought: Political Difference in Nancy, Lefort, Badiou and Laclau, Edinburgh: Edinburgh University Press, 2007, pp. 38-43.

Patočka Jan, Heretical Essays in the Philosophy of History, op. cit., p. 42.

44 There is, without a doubt, more to be said about Patočka's understanding of politics, and of his understanding of political coexistence, but this transcends the scope of this article. Here I can just mention that such a study should engage in a reading of Patočka where his thought is put in dialogue with other political thinkers, and then especially with the work of Claude Lefort. Lefort is interesting in this context since he and Patočka seem to conceptualise the question of political coexistence in a similar way. Analogously to the way in which Patocka understands the question, Lefort also stresses the constitutive role that political antagonism plays concerning the construction of a political unity in conflict. See: Lefort Claude, "Permanence du théologico-politique?", in Lefort C., Essais sur le politique - XIXe-XXe siècles, Paris, Éditions du Seuil, 1986. 
jective phenomenology and his concomitant analysis of the world. It is a worldly coexistence and a form of coexistence that fluctuates between different degrees of proximity and distance by virtue of the temporal tension that permeates human existence and its constitutive worldliness. What Patočka is trying to come to terms with in his a-subjective phenomenology is, in other words, not only the possibility of a phenomenological analysis that takes the world or appearing as such, rather than the subject, as its starting point, but also the possibility of a phenomenology that displaces its traditional understanding of intersubjectivity in favour of an analysis of the constitutive and worldly coexistence of man. This is one of Patočka's lasting contributions to the phenomenological tradition, but it is also one of his most important contributions to the discussions concerning the question of coexistence or community in contemporary thought. ${ }^{45}$

Gustav Strandberg is a lecturer in Philosophy at Södertörn University, Stockholm, Sweden. His main areas of research are phenomenology, political philosophy, aesthetics, and Marxist thought. Recent publications include his dissertation Politikens omskakning - Negativitet, frihet och samexistens in Jan Patocka's thought (English title: The Tremor of Politics - Negativity, Freedom, and Coexistence in the Thought of Jan Patočka).

E-mail: gustav.strandberg@sh.se

45 Here I am thinking of the debates and discussions on the question of community that we find in the work of Jean-Luc Nancy, Maurice Blanchot, and Giorgio Agamben (to mention only the most central names involved in these discussions). 